\title{
Proposal for the Creation of a Network of Family Businesses in the Mexican Coffee Industry
}

\author{
Jesús Israel Morales Hernández ${ }^{1}$, Maria Luisa Mendez², Sara Perla Nolasco \\ Ruíz ${ }^{3}$, Marco Tulio Cerón López ${ }^{4}$
}

\author{
${ }^{1}$ Doctoral student in Strategic Planning and Technology Division UPAEP, \\ jesusisrael.morales@upaep.com.mx \\ ${ }^{2}$ Doctoral student in Strategic Planning and Technology Division UPAEP, \\ marialuisa.mendez01@upaep.com.mx \\ ${ }^{3}$ Doctoral student in Strategic Planning and Technology Division UPAEP, saraperla.nolasco@upaep.edu.mx \\ ${ }^{4}$ Researcher, Division UPAEP \\ marcotulio.ceron@upaep.mx
}

\begin{abstract}
This article seeks to contribute to the union of Mexican coffee growers, growth and development of our coffee industry and increased commercial involvement by creating a network where family firms undertake strategic alliances, share and comply with standards of communication, technology, management information and knowledge, among others. Explanatory and descriptive documentary analysis of the importance of coffee farmer in Mexico category was performed in order to propose a Network model of Coffee in Mexico. The main pillars on which rests the network are: information, technology, knowledge and goods and services.
\end{abstract}

Keywords-coffee, family business, networks.

Resumen-Este artículo busca contribuir a la unión de los cafeticultores mexicanos, el crecimiento y desarrollo de nuestra industria cafetalera y una mayor participación comercial mediante la creación de una red donde las empresas familiares realicen alianzas estratégicas, compartan y cumplan con estándares de comunicación, tecnología, administración, información y conocimientos, entre otros. Se realizó un análisis documental explicativo y descriptivo sobre la importancia del rubro cafeticultor en México, para posteriormente proponer un modelo de Red del Café en México. Los principales pilares en los que descansa la red son la información, la tecnología, los conocimientos y los bienes y servicios.

Palabras Clave: café, empresas familiares, redes.

\section{INTRODUCTION}

Coffee, source of many stories, legends and traditions, is a native beverage universally known, originating in Ethiopia
Africa that comes from a plant called coffee, of which there are several varieties in the world. Greather production worldwide is the family of the Arabian with 70 percent of production, this is followed by the robust, originating from Uganda and its main producer is Vietnam. To Mexico, coffee is the second product in volume of our exports, oil is number one. Brazil being the main producer (Almazara, 2012).

Today, the coffee industry is facing a very competitive and industrialized world, coffee being one of the main agricultural products consumed worldwide. Mexico is one of the leading producers of coffee, ranking sixth as a producer (Amecafe, 2012), thanks to national geography that allows cultivate and produce ranked among the world's best varieties, which are grown in twelve states of the Mexican Republic in an area of 688,718 hectares (Siap, 2010), Chiapas is still the main producer of this grain. Moreover, Mexico ranks first in the production of organic coffee.

Moreover, the production of coffee has ancestral population presented different problems of development and marginalization; its inhabitants, most of whom come from ethnic groups have suffered abuse and exploitation of third due to the lack of a more equitable for its handicraft and agricultural products trade process, as buyers and exporters who are governed by the laws of the local market for their products, this results in cheaper products.

It is for this that the coffee industry in Mexico, should updated, renew and be in constant innovation and development, in addition coffee producers need to organize themselves for the production and penetration into national and international markets in a better and greater way. 
This article is intended to contribute to the growth and development of the coffee industry and the organization of producers of Mexican coffee through the identification of factors that allow these producers integrated into a system of enterprise network for improvement, promotion and development of coffee companies in Mexico and promote more and better participation of Mexican coffee industry in domestic and international markets. In-Network seeks that family businesses share and make strategic alliances, meet the standards of communication, technology, management, information, knowledge, goods and services and support each other for the growth of all members of the network. This work consists of the introduction, description of coffee cultivation in Mexico, the theoretical framework, the results and conclusions.

Coffee cultivation in Mexico According to the Mexican Association of Coffee Production Chain AC Amecafe demand / annual coffee consumption in the international context it is 134 million bags of $60 \mathrm{~kg}$, while the supply / annual production is 133 million bags and 24 million bags of inventory. (Amecafe, 2014), so we notice that the market is very balanced.

For Mexico, according to figures from 2011-2012, as shown in Chart 1, the coffee is a strategic activity in the economic sphere; and employing more than 500,000 producers, about 690,000 hectares 12 states and 391 municipalities and involves Mexican exports 897,000,000 per year, making our country the leading producer of organic coffee in the world and destines 10 percent of its surface to this activity. In addition, coffee production directly and indirectly linked to nearly 3,000,000 people and generates a market value of about 20 billions pesos per year (Sagarpa, 2014).

\section{Chart 1}

\section{Distribución de la Poducción de Café Convencional 2011}

\begin{tabular}{cl}
\hline $\begin{array}{c}\text { \% de la } \\
\text { Superficie } \\
\text { sembrada }\end{array}$ & \multicolumn{1}{c}{ Estados } \\
\hline 84 & Chiapas, Veracruz, Oaxaca y Puebla \\
15 & Guerrero, San Luis Potosí, Nayarit e Hidalgo \\
1 & Jalisco, Querétaro y Tabasco \\
\hline
\end{tabular}

Fuente: sagarpa.gob.mx.

The coffee production chain is one of the most important items in the agribusiness sector in the country, not only for its economic importance, but also the social and environmental impact generated. As mentioned above, the positioning of coffee both in the field of international market as in the domestic market is one of the strategic actions in the economic field for all involved in this system in coffee production. (See chart 2).

In Mexico, the coffee industry is mainly grouped in family enterprises, mainly in the agricultural part of the process, not in the marketing or processing of the coffee cherry. It is in the process of agriculture, where it is important that its members have values, socialize smoothly and seek to achieve shared goals. That is, people with empathy, availability, perseverance, collaborating with the same objective, organized in family businesses are the ones most likely to succeed through an associative process, to join and share the results on a network or business consortium. (Vargas J. y Ticlla E, 2012).

\section{Chart 2}


Datos Básicos del Cultivo del Café

\begin{tabular}{|c|c|c|c|}
\hline & Concepto & U de $\mathbf{M}$ & Cantidad \\
\hline \multirow{11}{*}{$\begin{array}{l}\text { Producción } \\
\text { Nacional } \\
(\mathbf{2 0 1 1 / 1 2 )}\end{array}$} & Superficie sembrada en 12 estados (miles) & $\mathrm{Ha}$ & 760.4 \\
\hline & Superficie cosechada (miles) & $\mathrm{Ha}$ & 687.7 \\
\hline & Composición de la superficie & $\%$ & $97 \%$ arábigo y $3 \%$ robusta \\
\hline & Rendimiento (café cereza) & Ton/ha & 1.86 \\
\hline & Producción anual de café cereza (miles) & Ton & $1,285.80$ \\
\hline & Sacos de café oro, beneficiado o verde de $60 \mathrm{~kg}$ & Miles & $4,286.10$ \\
\hline & Quintales de café oro, beneficiado o verde ( $45 \mathrm{~kg})$ & Miles & $5,590.50$ \\
\hline & Valor de la producción (millones) & $\$$ & $6,806.90$ \\
\hline & $\begin{array}{l}\text { Número de productores ( } 80 \% \text { zonas marginales, } \\
66 \% \text { indígenas) }\end{array}$ & Miles & 542.20 \\
\hline & Productores de café orgánico & $\%$ & 7 \\
\hline & Estacionalidad de la producción & $\%$ & El $66 \%$ se optiene de enero a marzo \\
\hline \multirow{7}{*}{ Comercio } & Quintales comercializados cíclo 2011/2012 & Miles & $2,524.80$ \\
\hline & Exportación ciclo 2011/2012 (Miles) & Sacos de $60 \mathrm{Kg}$ & $3,375.00$ \\
\hline & Valor de exportación (millones) & Dólar/pesos & $875.9 / 11,647.2$ \\
\hline & Consumo per capita & $\mathrm{kg} /$ anuales & 1.43 \\
\hline & \multirow[t]{3}{*}{ La composición porcentual de la exportación en: } & café verde & 76 \\
\hline & & Industrializado & 23 \\
\hline & & Tostado y molido & 1 \\
\hline
\end{tabular}

Nota: El ciclo cafetalero es de octubre de un año a septiembre del siguiente

Elaborado con datos del SIAP, PNC, OIC y AMECAFE 2012.

Fuente: sagarpa.gob.mx

On the other hand, according to the Business Families Foundation (2013), Mexico is the fifth country with more family businesses in the world, generating these companies 90 percent of GDP and yet these are a vital part of the economy, facing a number of problems that limit their growth, maturation and permanency in the market, being the main ones the following.

- 70 percent of new businesses do not reach the third year of life.

- Do not have a succession plan.

- The recruitment is usually done with emotional and non-strategic bases

- Do not have a driving organ itself, eg a Board of Directors.

- There is no practice of monitoring budgets and business plans.

It is for this that according to Giovannuncci and Ponte (2010), in the current context of the global market, you can analyze the dynamics of sustainability in the coffee sector taking into account the role of different role players such as government and industry associations public and private, they constitute the regulatory framework in any specific sector. In this context, Bacon (2010) links the changes in world coffee markets with the opportunities and vulnerabilities to sustain the livelihoods of farmers. The changes that characterize the cris is in conventional coffee markets are changing governance structures, corporate concentration, and oversupply of coffee bean and low prices. By contrast, certification of organic and fair trade is two alternative forms of trade and production of specialty coffees that can provide opportunities for small-scale producers.

Moreover, Palacios (2004), paying attention not only to the dynamics in the production and trade, but also the role of agents of mediation area, in this case the state agencies of different character, ensures that the influence expansion of global trade networks, under state protection in certain ecological-cultural ${ }^{1}$ and despite its purported cultural authenticity niches are strategically in situations of dependence due to its roughly inferred monoculture of certain commercial products accession, as would be coffee. Another problem facing the coffee sector is the drastic reduction of government support for the sector, because as we can see in chart 3, support the productive promotion of

${ }^{1}$ Ecological-cultural niche is how an organism is related to their biotic and abiotic environment. In other words the niche is the role and the place of an organism in an ecosystem. 
coffee has fallen in recent years compared to 2010, approximately 50 percent.

As a result of reduced government support the productive promotion, an equally drastic reduction in the number of Chart 3

Apoyo a Fomento Productivo del Café 2007-2012 coffee producers benefit compared to 2010 is observed, as shown in chart 4.

Monto Distribuido (pesos)

\begin{tabular}{|c|c|c|c|c|c|c|}
\hline Entidad & 2007 & 2008 & 2009 & 2010 & 2011 & 2012 \\
\hline Chiapas & $162,816,740.50$ & $181,562,919.50$ & $189,527,424.00$ & $176,726,967.69$ & $68,351,783.64$ & $103,874,139.38$ \\
\hline Colima & $906,596.00$ & $560,677.50$ & $1,061,838.00$ & $1,106,875.83$ & $409,824.70$ & $524,660.94$ \\
\hline Guerrero & $20,714,923.50$ & $25,611,743.00$ & $28,407,998.00$ & $27,590,988.90$ & $13,417,513.77$ & $15,389,488.14$ \\
\hline Hidalgo & $9,042,172.50$ & $2,539,379.00$ & $3,741,113.97$ & $3,836,899.98$ & $2,314,653.76$ & $2,760,214.79$ \\
\hline Jalisco & $181,788.00$ & $219,189.50$ & $1,143,530.36$ & $1,183,095.22$ & $62,192.52$ & $177,839.15$ \\
\hline Nayarit & $12,143,894.00$ & $13,105,081.50$ & $17,733,563.00$ & $17,097,670.54$ & $7,558,563.87$ & $10,841,986.24$ \\
\hline Oaxaca & $73,220,460.00$ & $85,720,354.00$ & $93,890,889.34$ & $88,164,244.04$ & $36,850,474.29$ & $44,298,043.90$ \\
\hline Puebla & $42,743,506.00$ & $39,290,134.00$ & $47,209,350.16$ & $44,835,253.05$ & $21,288,719.16$ & $27,282,588.59$ \\
\hline Querétaro & $69,600.00$ & $1,150.00$ & $1,000.00$ & 950.00 & $3,571.60$ & $3,399.97$ \\
\hline San Luis Potosí & $4,287,025.50$ & $6,103,960.50$ & $7,038,938.04$ & $7,187,544.45$ & $3,043,898.59$ & $2,774,643.53$ \\
\hline Tabasco & $316,150.00$ & 650.00 & 650.00 & 617.50 & & \\
\hline Veracruz & $109,560,620.00$ & $104,351,305.50$ & $112,896,271.19$ & $106,398,874.56$ & $58,729,796.25$ & $82,499,481.75$ \\
\hline Total & $436,003,476.00$ & $459,066,544.00$ & $\mathbf{5 0 2 , 6 5 2 , 5 6 6 . 0 6}$ & 474,129,981.76 & $212,030,992.15$ & $290,426,486.38$ \\
\hline
\end{tabular}

Moreover, investment in research and development in the coffee sector reported a low level of activities of this type, while the lack of cooperation with the institutions that conduct research, development and innovation directly affects the competitiveness of studied sector (Becerra F. and H. Serna 2012).

It should be noted in this regard that the Secretariat of Agriculture, Livestock, Rural Development, Fisheries and Food (Sagarpa) has developed in recent years a particular program to encourage expenditure on research and development, it has called Procafe ${ }^{2}$, which announced a budget exercise for $2014700,000,000$ pesos. This resource aims to link producers with technological innovation in the development of infrastructure such as technologically advanced plants to mitigate the shortcomings caused by the existence of pests and the effects of climate change. This program links teamwork of producers, traders and scientists to find ways to help reactivate the coffee field.

${ }^{2}$ Procafe building program for agriculture which seeks to help increase production and productivity of agricultural rural economic units engaged in coffee cultivation in Mexico 


\section{Apoyo a Fomento Productivo del Café 2007-2012}

Número de Productores Beneficiados

\begin{tabular}{|c|c|c|c|c|c|c|}
\hline Entidad & 2007 & 2008 & 2009 & 2010 & 2011 & 2012 \\
\hline Chiapas & 108,530 & 107,044 & 113,203 & 114,543 & 51,082 & 54,106 \\
\hline Colima & 519 & 178 & 430 & 794 & 275 & 294 \\
\hline Guerrero & 12,401 & 11,824 & 12,897 & 13,838 & 9,811 & 9,950 \\
\hline Hidalgo & 24,585 & 2,112 & 3,125 & 3,952 & 2,541 & 2,360 \\
\hline Jalisco & 536 & 30 & 180 & 258 & 36 & 60 \\
\hline Nayarit & 3,167 & 2,997 & 3,942 & 6,599 & 2,427 & 2,497 \\
\hline Oaxaca & 59,971 & 49,311 & 53,462 & 55,310 & 29,749 & 28,241 \\
\hline Puebla & 29,439 & 27,129 & 30,547 & 30,747 & 17,728 & 15,060 \\
\hline Querétaro & 217 & 1 & 1 & 1 & 8 & 8 \\
\hline San Luis Potosí & 9,717 & 4,803 & 5,701 & 5,752 & 4,034 & 3,080 \\
\hline Tabasco & 971 & 1 & 1 & 1 & 0 & 0 \\
\hline Veracruz & 60,438 & 54,040 & 58,606 & 57,814 & 37,740 & 36,433 \\
\hline Total & 310,491 & 259,470 & 282,095 & 289,609 & 155,431 & 152,089 \\
\hline
\end{tabular}

Elaborado con datos del SIAP, PNC, OIC y AMECAFE.

Fuente: sagarpa.gob.mx

It is therefore important coffee growing internationalization of coffee Pymes, since programs are based on the construction of sectoral, regional and national competitiveness through the cooperative relationship between companies in the same industry, which are integrated to access projects with high risk, but essential for exploiting new markets through the development of activities to build a joint competitive strategy (Durán 2011). The coffee industry should be supported by institutions supporting enterprise networks formed with technical skills, reputation, legitimacy, neutrality and territorial presence; Also, for a regulatory framework conducive business environment, containing restrictions as conditions and consistent with external regulations.

Founded on the above, there are, according to the Ministry of Economy of the Mexican government; four main as sociations representing the coffee industry:

1. The Mexican Association of Coffee Production Chain (Amecafe). Emerges in 2006, in order to group the sectors involved in the agricultural process Emerges in 2006, in order to group the sectors involved in the agricultural, agro-industrial coffee processing; process from planting to retail in the domestic and international market. Its mission is to make coffee growing so conducive to regional development and income generation for everyone in the chain profitable and sustainable.

2. The National Association of Coffee Industry AC (Canacafe). Founded in 1976 by a group of private companies. Today it involved 35 partners that manufacture and market instant coffee, roasted, ground and decaffeinated.

3. Coffees of Mexico. It was founded in 1985 as a channel of communication and liais on between all actors that are part of the coffee production chain. Report the outstanding activities at national and international coffee sector. Acts as the registration entity and select the topics of interest to the industry.

4. The Mexican Association of Coffee and Cafes AC Born in August 2004, its main function is to satisfy the needs of coffee bars, cafes and specialty coffee sector. Helps to find suppliers for goods, equipment, furniture, advice and training for a coffee shop. Boost coffee consumption in Mexico. 
Note that each and every one of the above organizations plays a different role that often fails to complement a joint vision to maturity and sustainability of the sector on issues such as productivity, research and development and maturity enterprise networks that enable the positioning of the industry as one of the most important in Mexico.

\section{THEORETICAL FRAMEWORK}

Regarding sistemic structure of a network, it comprises three basic elements: nodes, which are the components (individuals, organizations, etc.) between which links of interest occur; relationships or exchanges of information, knowledge, technology, goods and services, etc., which essentially define and govern the behavior of the network; and finally communication, which can be determined by the (formal or informal) social roles played by nodes within the (Becerra, 2008) network.

According to Soto (2010), one of the research topics in the subject of coffee, is to evaluate the characteristics of the plant, since a more sustainable coffee system could be developed to better conservation of natural resources; this author argues that the relationship between the characteristics of the coffee plant has significant effects on production yields.

Venezuelan authors Narváez and Fernandez (2013) mention as to the Business Cooperation Networks ${ }^{3}$, the results indicate the formation of these is based on certain stocks comprising the relational dimension called Social Capital ${ }^{4}$. It also has as important factors promoting Social Capital, the fact that micro enterprises seen as key requirements for successful partner in a corporate network or consortium members possess values, socialize smoothly and ownership of shared goals. Is that people with empathy, availability, perseverance, and collaborating with the same goal are for micro-enterprises are more likely to succeed through an as sociative process. (Vargas and Ticlla 2012).

${ }^{3}$ Organizational structures, which consist of several companies, communicated and interrelated, to carry out joint projects without the need to create superstructures that would take them out individually.

4 Social capital is an accounting term that is associated with the value of property or money that partners bring to a company without right of return
It also mentions that the traditional perspectives of social and economic development in the regions are giving way to more comprehensive views that include factors such as the interactions between agents, the peculiarity of the territories, cultural norms that govern human relations and the role that institutions can play. So that the promotion of social capital, in which the ability to form and nurture networking among regional actors, to foster a culture based on trust and cooperative values and strengthen effective institutions and policies and transparent included represents an important asset for achieving sustainable social development. (Rodriguez, 2012).

Another important aspect of enterprise networks reside in the institutions that support it, must comply with these technical skills, reputation, legitimacy, neutrality and territorial presence, accompanied by a regulatory framework conducive business environment and contains both constraints and conditions and consistency with external regulations. Mentioned as important external regulations dynamics of markets (government value chain), access to markets (dominant business strategy), patents, licenses, intellectual property, institutional environment and territorial, the sophistication of business strategy and access to productive factors and technologies. (Workshop Production Integration Projects Mif, Washington DC, October 2007).

As a family business, the essential elements that comprise are the property, business and family. With these elements one can say that the family business is one business organization in which ownership of the instrumental means and / or address are operationally in the hands of a group whose members family relationship exists. (Vélez, Holguín, De la Hoz and Duran, 2008).

Some other authors define the family business as one economic organization whose main purpose is the production or marketing of goods or services, and which are owned wholly or mostly a group of people united by family ties usually the descendants of the founder of it. (Thomas, 2008).

Family businesses as Gonzalo (2011) and Romero (2011) are the backbone of economic development, because in a market economy, the entrepreneur is the key. If there is no business, no company, no creation of jobs, no wealth creation.

\section{METHODOLOGY}

To deepen this investigation the need to address it with the understanding that it is a reality in constant change (dialectical aspect) so the dialectical method is hereby 
established. Moreover, there was the need based on existing theory, documentary research in libraries, databases and Internet, using national and international literature sources; Likewise, it was necessary to present a documentary analysis of the current role of family businesses in the coffee industry in Mexico and a documentary analysis of the model proposed in Red Coffee in Mexico, based on the variables of this. Finally, once the instruments of process analysis and interpretation of the information used, the synthesis that would allow the establishment of conclusions (synthetic aspect) was performed.

\section{RESULTS}

Then the diagram on the proposed establishment of the Network of Family Businesses in the Mexican coffee industry, allowing the union, the link and benefit to everyone involved is shown.

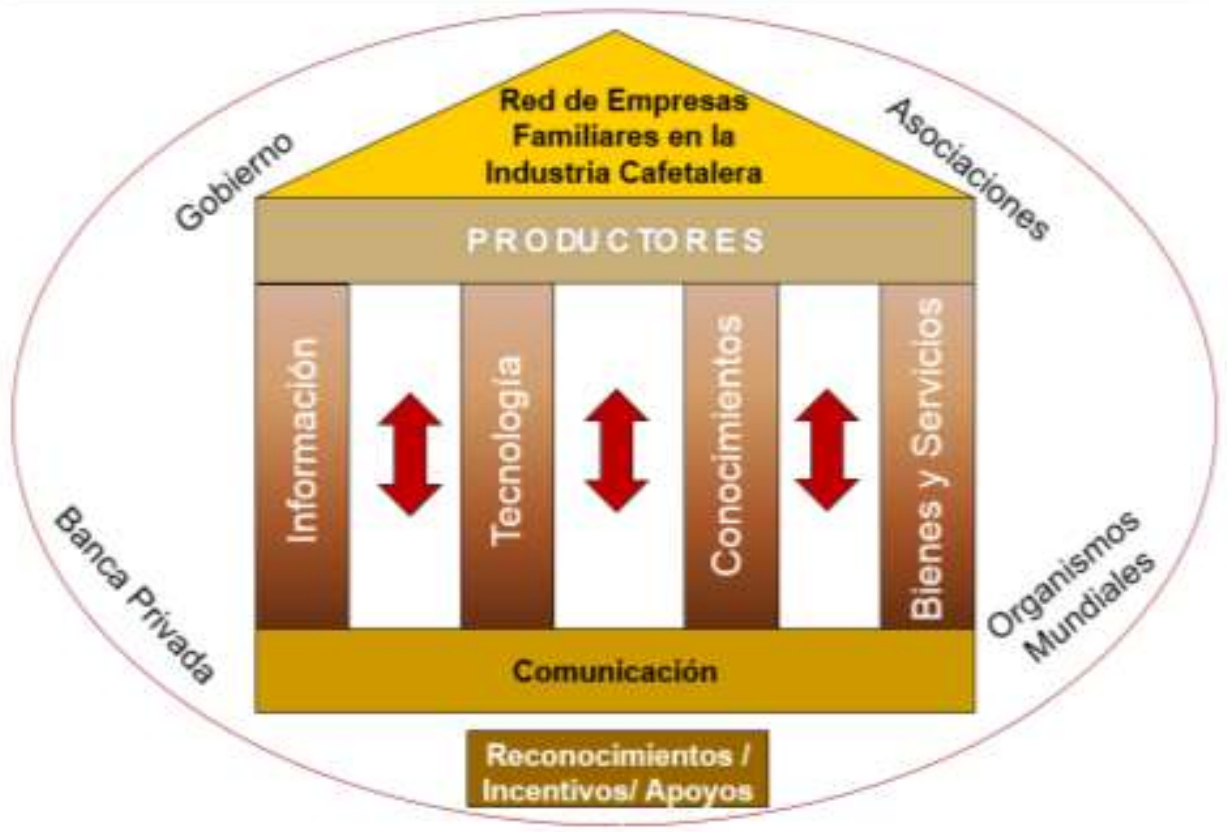

This proposal shows at the top of the familares coffee companies that are producing party; they are supported in the foundation of communication holding four pillars. The first is information, where it is important that family businesses have databases that allow first instance those companies will create its history and statistics. Moreover, this information may be shared with others in the industry to make comparisons to identify best practices to be shared to benefit family businesses. The company information must be clear and concise so as to allow an auditable process.

As second pillar is the technology, which in this case can include a wide range of disciplines such as computer science, automation, robotics, pneumatics, electronics, and others. The notion of technology should be linked to all knowledge to make objects and modify the environment, intended to satisfy a need. Family businesses should have access to credit that allows them to purchase machinery and equipment. Especially in the processes that need to be optimized, such as family businesses often do not have sufficient capital to have an automated line. However, the proposed technology aims to get equipment to support certain processes of the supply chain. For example, get the equipment to product packaging, pulping machine, toaster machine, etc.

Knowledge is a third pillar of family businesses, in which the expected contribution of the producers is to contribute to the network experience in their specific field and specialization of the production process for the production and marketing of coffee.

Finally, we have the pillar of goods and services, where importance is that the producer count in their home with at least the minimum infrastructure required for their production process and the state to provide basic services such so the producers to have this, improve their working conditions, they can be useful and will be reflected in improved productivity.

\section{CONCLUSIONS}

The creation of an enterprise network join the coffee production chain, as well as the main regulatory organizations, associations and twelve states leading coffee producers in Mexico, considering the common interests 
with all these actors for increasing and improving the different stages of production and marketing of coffee.

Likewise, in the future family coffee companies could gain a competitive advantage as they have the support of a mature business network that offers a number of benefits that currently do not have, these are the benefits: Interact with business owners, b) Exchange of information and technology, c) Identify market opportunities, d) Permit be informed of the commercial, government and social events. And besides, network will serve as a showcase for products of all members of coffee industry so if the network does have a structure of the proposal described in the results section, the company may have a demand orientation, an orientation towards the entrepreneur, business guidance and finally, an orientation to the generation of permanent changes in the production structure of entrepreneurs.

It is suggested as a complement to the success of the network, a review of the current context of government support to coffee producers, which is comprised of programs to support family businesses, organizations and associations in the coffee category that are created by the government.

It is suggested as a complement to the success of the network, a review of the current context of government support to coffee producers, which is comprised of programs to support family businesses, organizations and associations in the coffee category that are created by the government.

Also, conducting a Swot analysis in the sector in order to identify opportunities and weaknesses in the sector, to promote and implement new growth strategies, such as the fair trade and increasing certifications in products is suggested the increased production of organic coffee cultivation in Mexico which so far has the first place worldwide.

Continuously perform research and development in the sector and constant research of world markets, sending this information to coffee farmers through the proposed enterprise network. Overall emphasize the need for the corporate network is in constant awareness of the global environment, to continually circulate information, which may provide constantly updated to family coffee companies, for further growth of this industry.

All this adds up to ensure sustainable economic growth strategy to help raise growth rates of income and output per capita coffee producing regions, making conditions conducive to improving the quality of life of farmers, reducing poverty and preserving natural resources when growing coffee.

\section{REFERENCES}

[1] Almazara E. (2012). De viandas y brebajes café. , Contactos.83, 52-56. El 16/12/2012.

[2] Arce, B. Martínez, E. (2007). "Modelo de desarrollo integral para empresas familiares e productos no tradicionales, asociadas al cultivo del café". Tecsistecatl. Revista electrónica de ciencias sociales, revista interdiciplinar 1. http://www.eumet.net/rev/tecsistecatl/n0/acmd1.htm diciembre 2013.

[3] Bacon C. (2005) Confronting the Coffee Crisis: Can Fair Trade, Organic, and Specialty Coffees Reduce Small-Scale Farmer Vulnerability in Northern Nicaragua? World Development Vol. 33, No. 3, pp. 497-511, 2005.

[4] Becerra, F.Serna H. (2013). Redes empresariales locales y su incidencia en la innovación de la empresa. Revista Venezolana de Gerencia (RVG). Año 17. $N^{\circ}$ 57, 2012, 113 - 131. Universidad del Zulia (LUZ) _ ISSN 1315-9984.

[5] Becerra R, Fredy. (2008). Las redes empresariales y la dinámica de la empresa: aproximación teórica. Innovar. Revista de ciencias administrativas y sociales, Vol. 18, Núm.32, Julio-diciembre, 2008, pp. 27-45.

[6] Durán W. (2011). Redes Empresariales: Experiencias y Estrategias para el desarrollo de la competitividad en las regiones. Revista MBA. Num 2. Dic. 2011.

[7] Giovannucci D, Ponte S. (2005), Standards as a new form of social contract. Sustainability initiatives in the coffee industry. Food Policy. 284-301.

[8] Lora, E. (2013). Crecimiento sustentable. Documento de estrategia. Banco Interamericano de desarrollo. Departamento de desarrollo sustentable. Washington, pp.1-38.

[9] Maggui C. (2007) "V Taller Proyectos de Integración Productiva FOMIN", ponencia presentada en la Conferencia Gobernanza en Redes Empresariales, Washington DC.

[10] Narváez, M. Fernández, G. (2013). Redes de cooperación empresarial: Relaciones e interacciones para promover desarrollo turístico local, Revista Venezolana de Gerencia, vol. 18, núm 61, pp. 121137.

[11] Palacios, J. (2009), Dilemas ecológicos-culturales en torno al café en la sierra mexicana Gazeta de Antropología. Artículo 24, pp. 1-8. 
[12] Rodríguez P. (2012). Análisis relacional del capital social y el desarrollo de los sistemas productivos regionales. REDES-Revista hispana para el análisis de redes sociales Vol.23, pp. 9.

[13] SAGARPA (Secretaría de Agricultura Ganadería desarrollo Rural Pesca y Alimentación). (2014) "Producción Nacional de café". SAGARPA, México, www.sagarpa.gob enero 2014.

[14] SHCP (Secretaría de Hacienda y Credito Público) (2014) “Dirección General Adjusnta de Planeación Estratégica, Análisis Sectorial y Tecnologías de la Información”. SHCP, México, www.financierarural.gob.mx enero 2014.

[15] Soto L, Perfecto I, Castillo J y Caballero J. (2000), Shade effect on coffee production at the northern Tzeltal zone of the state of Chiapas, Mexico, Agriculture, ecosystems and environment, pp. 61-69.

[16] Tomás J, (2009). Trampas genéricas de la empresa familiar, tipologías y casos. Ediciones Garnica, S.A. Barcelona, España.

[17] Vargas J. Ticlla E. (2012). Los factores que favorecen o limitan el fortalecimiento del capital Social en los procesos de Asociatividad. El caso de la red de microempresarias de confecciones de San Juan de Lurigancho. Tesis para optar el grado de Magíster en Gerencia Social. Pontificia Universidad Católica del Perú.

[18] Vélez D, Holguín H, De la Hoz G y Duran Y (2008). Dinámica de la empresa familiar PYME. FUNDES, 5. 